\title{
Diyarbakır Devlet Hastanesi çalışanlarında HBV, HCV, HIV, VDRL seropozitifliğinin ve aşılanma oranlarının belirlenmesi
}

\author{
Determination of HBV, HCV, HIV, VDRL seropositivity and vaccination rates in Diyarbakır State Hospital workers
}

\author{
Ahsen Öncül*a, Selda Aslan ${ }^{b}$, Habibe Pirinççioğluc ${ }^{c}$ Erdal Özbek $^{d}$ \\ ${ }^{a}$ Enfeksiyon Hastalıklarl ve Klinik Mikrobiyoloji Kliniği, Giresun A. İlhan Özdemir Devlet Hastanesi, Giresun, Türkiye \\ ${ }^{b}$ Enfeksiyon Hastalıklarl ve Klinik Mikrobiyoloji Kliniği, Gaziantep Çocuk Hastanesi, Gaziantep, Türkiye \\ ${ }^{c}$ Enfeksiyon Hastalıkları ve Klinik Mikrobiyoloji Kliniği, Diyarbakır Ĕ̆itim ve Araştırma Hastanesi, Diyarbakır, Türkiye \\ ${ }^{d}$ Mikrobiyoloji Laboratuvarı, Diyarbakır Kadın Doğum ve Çocuk Hastalıkları Hastanesi, Diyarbakır, Türkiye
}

\begin{tabular}{|c|c|}
\hline MAKALE I & GÍLERİ \\
\hline Makale geçı & \\
\hline Geliş tarihi & $: 28 / 05 / 2012$ \\
\hline Kabul tarihi & : $01 / 06 / 2012$ \\
\hline
\end{tabular}

\section{* Yazıșma Adresi:}

Ahsen Öncül

Giresun A. İlhan Özdemir

Devlet Hastanesi,

Enfeksiyon Hastalıkları ve

Klinik Mikrobiyoloji Kliniği,

Giresun

e posta: onculahsen@gmail.com

\section{Anahtar Kelimeler:}

Sağlık çalışanları

HBV

$\mathrm{HCV}$

HIV

VDRL

\section{Keywords:}

Healthcare workers

HBV

$\mathrm{HCV}$

HIV

VDRL

\section{ÖZET}

Bu çalışmanın amacı Diyarbakır Devlet Hastanesi'nde 2009 yılında çalışmakta olan sağlık personellerinde HBV (hepatit B virüsü), HCV (hepatit C virüsü), HIV (insan immünyetmezlik virüsü) ile sifiliz seropozitifliğinin araştırılması ve aşılanma oranlarının tespiti idi. Sağlık çalışanları enfeksiyon kontrol programı dahilinde hepatit taraması amaçlı enfeksiyon hastalıkları polikliniğine yönlendirildi. Yüzde 43,1'i sekreter, \%56,9'u hasta bakımı ile ilgili birimlerde çalışan personel olmak üzere 503 sağlık çalışanının serum örneklerinde hepatit B yüzey antijeni (HBsAg), hepatit B yüzey antikoru (anti HBs), HCV antikoru (anti HCV) ve HIV antikoru (anti HIV), VDRL tetkikleri çalışıldı. Aşılanma durumları ve iğne batması ile ilgili sorular cevaplayanlar üzerinden değerlendirildi. Beş temizlik personeli, 2 hemşire, 1 sekreter HBsAg pozitif bulundu. Sağlık çalışanlarında hepatit B seroprevalansı \%1,6 olup en sık görülen meslekler \%2,8 ile temizlik personelleri, \%2,7 ile hemşireler olmakla beraber fark anlamlı değildi. Hiçbir çalışanda HCV, HIV, VDRL seropozitifliği saptanmadı. Hepatit B bağışıklı̆̆ meslek gruplarına göre karşılaştırıldığında sağlık teknisyenlerinde $\% 94,4$, hemşirelerde $\% 90,5$, temizlik personelinde $\% 64,2$, sekreterlerde $\% 45,6$ bulundu ve aradaki fark istatistiksel olarak anlamlıydı. Tetanoz aşılanma oranı en düşük $(\% 60,7)$ sekreterlerde iken hemşirelerin \%93'ü tetanoz aşısı olduklarını belirtti. Hepatit B aşılanma oranı ise riskli grup olmalarına rağmen en düşük $\% 38,2$ oranı ile temizlik personellerinde saptanıp, en yüksek aşılanma oran $1 \% 89,6$ ile hemşirelerdeydi. Kadınlarda tetanoz aşısı olma oranı $\% 74,3$, erkeklerde $\% 65,1$ olup fark istatistiksel olarak anlamlıd $1(p=0,03)$. Hepatit B aşılanma oranı ise cinsiyete göre farklılık göstermiyordu $(\mathrm{p}=0,11)$. Hemşire ve sağlık teknisyenlerinde HBV aşılama oranları iyi olmakla birlikte temizlik personellerinde aşılanma oranlarının iyileştirilmesi ve bulaşıcı hastalıklar ile ilgili bilinçlendirilmeleri gerekmektedir. Sağlık çalışanlarında yapılacak tarama testleri ile asemptomatik hepatit taşıyıcıları ve aşılanması gerekenler tespit edilmelidir.

J. Exp. Clin. Med., 2012; 29:280-284

\section{ABSTRACT}

The aim of this study was to investigate hepatitis B virus (HBV), hepatitis C virus (HCV), human immunodeficiency virus (HIV) and syphilis seropositivity of healthcare personnel working in Diyarbakır State Hospital in 2009, and to determine their immunization rates. Healthcare workers were conducted to infection policlinic for health screening as a part of infection control program. Five hundred three healthcare workers' serum was examined for hepatitis B surface antigen ( $\mathrm{HBsAg}$ ), hepatitis B surface antibody (anti HBs), HCV antibody (anti HCV) and HIV antibody (anti HIV), VDRL of whom $43.1 \%$ was secretary and $56.9 \%$ was personnel working for patient care. Questionnaire about immunization and needle stick injuries were evaluated for the participants that answered. Five cleaning employees, 2 nurses, 1 secretary were found to be HBsAg positive. Hepatitis B seroprevalance was $1.6 \%$ in healthcare workers. The most prevalent groups were cleaning employees with $2.8 \%$ and nurses with $2.7 \%$, but the difference was not statistically significant. None of the workers were seropositive for HCV, HIV, 
VDRL. When hepatitis B immunity was compared between professions, it was $94.4 \%$ in health technicians, $90.5 \%$ in nurses, $64.2 \%$ in cleaning staff, $45.6 \%$ in secretary with statistically significant difference. Ninety three percent of nurses stated that they had tetanus shot whereas tetanus vaccination rate was lowest in secretary with $60.7 \%$. Hepatitis B vaccination rate was lowest in cleaning staff with $38.2 \%$ although they were a risky group, and the highest vaccination rate was seen among nurses (89.6\%). Tetanus vaccination rate was $74.3 \%$ in women and $65.1 \%$ in men with statistically significant difference $(\mathrm{p}=0.03)$. Hepatitis $\mathrm{B}$ vaccination rate did not differ among sex $(\mathrm{p}=0.11)$. Cleaning employees should be informed about contagious diseases and their immunization rates has to be improved, whereas HBV immunization rates of nurses and technicians are good. Asymptomatic hepatitis carriers and the ones that should have vaccine shots can be detected with screening tests among healthcare workers.

J. Exp. Clin. Med., 2012; 29:280-284

(C) 2012 OMU

\section{Giriş}

Mesleki riskler tüm çalışanların en sık maruz kaldığı risk grubundadır. Özellik arz eden sağlık çalışanlarının en sık maruz kaldığı risklerin başında enfeksiyöz hastalıklar gelir. Çalışanların kan ve vücut sıvılarıyla temas etmeleri nedeniyle viral hepatit bulaşı sıklıkla maruz kalınan risktir. Enfeksiyon kontrol önlemlerinin kati olarak uygulanması, çalışanların sağlık taramaların yapılması ve sonuçlara göre aşılama programının oluşturulması bulaş riskini azaltacaktır. Dünya Sağlık Örgütünün (DSÖ) 2008 yılı verilerine göre dünya nüfusunun yaklaşı üçte biri HBV ile enfekte olup 350 milyon kronik Hepatit B Virüsü (HBV) enfeksiyonlu hasta mevcuttur (WHO, 2008). Ayrıca DSÖ verilerine göre her yıl yaklaşık 3-4 milyon yeni Hepatit C Virüsü (HCV) olgusu saptanmaktadır (Barut ve Günal, 2009). Ülkemizde ise HBV enfeksiyonu oranı değişkenlik göstermekte olup kabaca batıdan doğuya doğru prevalans artmaktadır. Özellikle Güneydoğu Anadolu bölgesinde yüksek endeminin görüldüğü Diyarbakır bölgesinde bu oran \%10'lara varmaktadır (Hepatit B Güncelleme, 2007; Mıstık, 2007). HCV ülkemizde ikinci sıklıkta yaygın olan kronik hepatit nedenidir (Mistık, 2007). Ülkemiz dünya genelindeki \%1-1,9 prevalans diliminde yer almaktadır (Barut ve Günal, 2009). Sağlık çalışanlarında bir diğer mesleki enfeksiyon riski ise HIV'dir. Ülkemizin dahil olduğu Doğu Avrupa, Orta Asya bölgesinde enfekte kişi sayısı son 10 yılda 3 kat artış göstermiştir. Ülkemizde 2010 yılında 279 yeni vaka bildirilerek tanı konmuş enfekte kişi sayısı 4177'ye ulaşmıştır (UNAIDS, 2010).

Çalışanların kan ve vücut sıvılarıyla sıklıkla temas etmeleri sıklıkla iğne batması nedeniyle olmaktadır. HBV enfeksiyonlu hastaya ait iğne batması ile bulaş riski; HBeAg negatif hastadan \%1-6, HBeAg pozitif hastadan \%22-40'dır (Mast ve Alter, 1993). HCV enfeksiyonlu hastaya ait iğne batmas1 ile serokonversiyon insidansı yaklaşık \% 1,8 olup iğne çapının artması ve yaranın derinliği ile orantılı olarak bulaş artmaktadır (Yazdanpanah ve ark., 2005). Aşı uygulaması ile enfeksiyonlara karşı koruyuculuk sağlanmaktadır. Özellikle HBV aşısının uygulanması ile \%95 oranında koruyuculuk sağlanıp mesleki risk minimuma indirilmektedir. Sonuçta DSÖ tarafından 1991 yılından itibaren uygulanan hepatit B bağışıklama programları ile bildirilen yeni vaka sayısında önemli azalma sağlanmıştır (Hou ve ark., 2005). HCV enfeksiyonu için aşılamanın mümkün olmaması nedeniyle kan ve vücut sıvıları temasına karşı koruyucu önlemlerin alınması, bulaş sonucu akut HCV enfeksiyonu geliştiğinde erken dönemde saptanması ve tedavi başlanması gerekir. Sağlık çalışanlarında kesici delici aletlerle yaralanma kanla bulaşan enfeksiyöz hastalıklar yanında tetanoz için de risk faktörüdür. Hastalık korunma ve kontrol merkezi (CDC) tüm erişkinlerin en az 3 dozluk Td şeklinde tetanoz aşılarının yapılmasını ve 10 yılda bir aşı rapelini önermektedir (CDC, 2011).

$\mathrm{Bu}$ çalışmada Diyarbakır Devlet Hastanesinde çalışmakta olan sağlık çalışanlarında HBV, HCV, HIV ve sifiliz prevalansının saptanması, bağışıklık durumunun saptanarak tetanoz ve HBV enfeksiyonuna karşı aşılanma programının başlatılması ile kurum genelinde aşılanma oranlarının arttırılması amaçlandı.

\section{Araştırma yöntemi}

2009 yılında Diyarbakır Devlet Hastanesinde çalışmakta olan sağlık çalışanları sağlık taraması amaçlı enfeksiyon hastalıkları polikliniğine yönlendirildi. Aşılanma durumları ve iğne batması ile ilgili anket soruları yüz yüze sorularak cevaplandırıldı. 503 sağlık çalışanında serolojik inceleme yapıldı, anket sorularının yanıtları değerlendirildi. Serum örneklerinde Modular Analytics E170 (ROCHE® İSVIÇRE) cihazı kullanılarak HBsAg, antiHBs, (Roche HCV version 3,0 kitleri kullanılarak) antiHCV ve antiHIV testleri elektrokemilüminesans immunolojik metodu ile araştırıldı. VDRL testleri, immunokromatografik yöntem ile kaset testleri (TOYO-TURKLAB®TÜRKIYE) kullanılarak çalışıldı. HBsAg pozitif bulunan sağlık çalışanları enfeksiyon hastalıkları polikliniğinden takibe alındı. Anti HBs negatif sağlık çalışanları aşı programına alındı. Tüm veriler 'SPSS 16,0 for windows' programına kaydedildi. Ki-kare testi verilerin analizi için kullanıldı.

\section{Sonuçlar}

Beşyüz üç sağlık çalışanı kan örneği vererek çalışmaya katıld1. Katılanların 296's1 $(\% 58,8)$ kadın, 207'si $(\% 41,2)$ erkekti. Çalışmaya katılanların \%43,1'i sekreter, \%56,9'u hasta bakımı ile ilgili birimlerde çalışan personeldi (\%35 temizlik personeli, \%14,7 hemşire, \% 7,2 sağl1k teknisyeni). Beş temizlik personeli, 2 hemşire, 1 sekreterde HBsAg pozitifliği saptandı. Sağlık çalışanlarında hepatit B pozitiflik seroprevalans $\% 1,6$ idi. Temizlik personelinde $\% 2,8$, hemşirelerde $\% 2,7$ olup istatistiksel olarak anlamlı fark mevcut değildi. Sağlık çalışanlarında HCV, HIV, VDRL tetkiklerinde seropozitiflik saptanmadı (Tablo 1). Çalışmaya katılan 503 kişiden 468'i hepatit B aşılanma durumu ile ilgili, 476'sı ise tetanoz aşılanma durumu ile ilgili soruları yanıtladı. Hepatit B aşıs1 yaptırdığını ifade edenlerde antiHBs seropozitifliği aşı ile ilişkilendirildi. Aşılama yapılmamış olanlarda antiHBs pozitifliğinin doğal bağışıklık olduğu düşünüldü. Hepatit B'ye 


\begin{tabular}{|c|c|c|c|c|c|c|}
\hline Meslek & $\begin{array}{c}\text { Personel } \\
\text { sayısı } \\
\text { n (\%) } \\
\end{array}$ & $\begin{array}{c}\text { HBsAg* } \\
\text { n (\%) }\end{array}$ & $\begin{array}{c}\text { AntiHBs** } \\
\text { n (\%) }\end{array}$ & $\begin{array}{l}\text { Anti } \\
\text { HCV } \\
\text { n(\%) }\end{array}$ & $\begin{array}{l}\text { Anti } \\
\text { HIV } \\
\text { n(\%) }\end{array}$ & $\begin{array}{l}\text { VDRL } \\
\text { n (\%) }\end{array}$ \\
\hline $\begin{array}{l}\text { Temizlik } \\
\text { personeli }\end{array}$ & $176(35)$ & $5(2,8)$ & $113(64,2)$ & - & - & - \\
\hline Hemşire & $74(14,7)$ & $2(2,7)$ & $67(90,5)$ & - & - & - \\
\hline $\begin{array}{l}\text { Sağlık } \\
\text { teknisyeni }\end{array}$ & $36(7,2)$ & $0(0)$ & $34(94,4)$ & - & - & \\
\hline Sekreter & $217(43,1)$ & $1(0,5)$ & $99(45,6)$ & - & - & - \\
\hline Toplam & $503(100)$ & $8(1,6)$ & $313(62,2)$ & - & - & - \\
\hline
\end{tabular}

karşı bağışıklık durumları Tablo 2 de özetlendi. Dörtyüz altmış sekiz kişiden 176'sında $(\% 37,6)$ HBV bağışıklığı yoktu. Yüzdört kişide $(\% 22,8)$ doğal bağışıklık, 188 kişide $(\% 40,2)$ aşıya bağlı bağışıklık tespit edildi. Doğal bağışıklık \%36,3 ile en yüksek temizlik personellerinde görülürken aşıya bağlı bağışıklık \%83,5 oranı ile en yüksek hemşire grubundaydı.

Toplamda antiHBs pozitifliği meslek gruplarına göre karşılaştırıldığında sağlık teknisyenlerinde $\% 94,4$, hemşirelerde $\% 90,5$, temizlik personelinde \%64,2, sekreterlerde \%45,6 bulundu ve aradaki fark istatistiksel olarak anlamlıydı (Tablo 1).

\begin{tabular}{|c|c|c|c|c|c|c|}
\hline \multirow[t]{2}{*}{ Meslek } & \multicolumn{2}{|c|}{$\begin{array}{r}\text { Doğal } \\
\text { bağışık }\end{array}$} & \multicolumn{2}{|c|}{$\begin{array}{c}\text { Aş̧ılı } \\
\text { bağışık }\end{array}$} & \multicolumn{2}{|c|}{$\begin{array}{c}\text { Bağışık } \\
\text { olmayan }\end{array}$} \\
\hline & $\mathbf{n}$ & $\%$ & $\mathbf{N}$ & $\%$ & n & $\%$ \\
\hline Temizlik personeli (n:165) & 60 & 36,3 & 44 & 26,6 & 61 & 36,9 \\
\hline Hemşire (n:67) & 5 & 7,4 & 56 & 83,5 & 6 & 8,9 \\
\hline Sağlık teknisyeni (n:33) & 5 & 15,1 & 26 & 78,8 & 2 & 6,1 \\
\hline Sekreter (n:203) & 34 & 16,7 & 62 & 30,5 & 107 & 52,7 \\
\hline Toplam (n:468) & 104 & 22,2 & 188 & 40,2 & 176 & 37,6 \\
\hline
\end{tabular}

Hepatit B ve tetanoza karşı aşılanma oranları meslekler arasında karşılaştırıldığında tetanoz aşılanma oranı en düşük $\% 60,7$ ile sekreterlerde iken hemşirelerin \%93'ü tetanoz aşıs1 yapıldığını belirtti (Tablo 3). Hepatit B aşılanma oranı ise riskli grup olmalarına rağmen en düşük \%38,2 ile temizlik personellerinde saptanıp, en yüksek aşılanma oranı \%89,6 ile hemşirelerdeydi. Aşılanma oranları açısından, meslekler aras1 görülen farklar istatistiksel olarak anlamlıydı $(\mathrm{p}<0,05)$.

Tablo 4'te görüldüğü gibi aşılanma oranları ile cinsiyetler karşılaştırıldığında kadınlarda tetanoz aşısı olma oranı $\% 74,3$, erkeklerde \%65,1 olup fark istatistiksel olarak anlamlıydı $(\mathrm{p}=0,03)$. Hepatit B aşılanma oranı ile cinsiyet karşılaştırıldığında istatistiksel olarak anlamlı fark saptanmadi $(p=0,11)$. İ̆ne batma öyküsü, HBsAg seropozitifliği, hepatit B bağ1şıklığı açısından da erkekler ile kadınlar arasında istatistiksel olarak anlamlı fark saptanmadı.

\begin{tabular}{|c|c|c|c|c|}
\hline & & \%) & $\begin{array}{l}\text { Erkek } \\
\text { n (\%) }\end{array}$ & p \\
\hline $\begin{array}{l}\text { Tetanoz aşısı olma } \\
\text { durumu }\end{array}$ & 211 & $(74,3)$ & $125(65,1)$ & 0,03 \\
\hline $\begin{array}{l}\text { Hepatit B aşısı olma } \\
\text { durumu }\end{array}$ & 148 & $(54,4)$ & $92 \quad(46,9)$ & 0,11 \\
\hline İğne batma öyküsü & 52 & $(18,4)$ & $32 \quad(16,5)$ & 0,58 \\
\hline HBsAg pozitifliği & 3 & $(1,0)$ & $5 \quad(2,4)$ & 0,21 \\
\hline $\begin{array}{l}\text { HBV bağışıklık } \\
\text { durumu }\end{array}$ & 179 & $(60,5)$ & $134(64,7)$ & 0,33 \\
\hline
\end{tabular}

\section{Tartışma}

Sağlık alanında çalışanlar kan ve vücut sıvılarıyla temas riski nedeniyle birçok enfeksiyon hastalığı için risk altındadır. Hastalık bulaşı aşılama, koruyucu ekipman kullanımı ve standart önlemlerin alınması ve maruziyet riskinin azaltılması ile engellenebilmektedir. Bu nedenle sağlık çalışanları için planlanan aşılama programında HBV, grip, kızamık, kızamıkçık, kabakulak ve suçiçeğine karşı aşılama kuvvetle önerilmektedir (CDC, 2011).

Sağlık çalışanlarının en sık maruz kaldığı enfeksiyöz risklerinin başında gelen HBV enfeksiyonundan dolayı yılda 100-200 sağlık çalışanının HBV enfeksiyonunun kronik komplikasyonlarından dolayı öldüğü tahmin edilmektedir (CDC, 2011). Hepatit B'nin prevalansı coğrafik bölgelere göre farklılık gösterip yüksek endemik $(\% 8)$, orta endemik (\%2-7), düşük endemik (<\%2) olarak bölgelere ayrılmaktadır (Hou ve ark., 2005). Türkiye orta endemik bölgededir ve nüfusun \%10-60'ının virüsle karşılaştığı ve karşılaşan kişilerin \%2-7'sinin kronik hepatit olduğu bilinmektedir. Yüksek endemik bölgelerde majör bulaş yolu perinatal ve çocukluk dönemindeki bulaşlar iken orta endemisitede mikst tipte (hem çocukluk hem de adolesan-erişkin dönem) bulaşmalar görülmektedir (Hou ve ark., 2005).

Ülkemizden yapılan çeşitli çalışmalarda sağlık çalışanlarında HBV seropozitifliği \%1 ile \%3 arasında değişmektedir (Aşkar, 2006; Demir ve ark., 2006; İnci ve ark., 2009; Öksüz ve ark., 2009; Yazıcı ve ark., 2010). Çalışmamızda bulunan $\% 1,6$ 'lık oran da literatürle uyumludur. Toplumda endemisite oranı arttıkça normal populasyon ile risk gruplarının HBV prevalansları arasındaki fark azalmaktadır. Örneğin sağlık personelinde HBV göstergelerinin pozitif bulunma oranı gelişmiş ülkelerde 3-5 kat fazla iken, orta-yüksek endemisite bölgelerinde bu oran birbirine yakındır (Taşyaran, 1998). HBsAg pozitifliği ile cinsiyet arasındaki farka bakılan Aşkar ve ark. nın yaptığı çalışmada istatistiksel olarak anlamlı fark saptanmadı. Yaptığımız çalışmamızda da benzer şekilde fark tespit edilmedi. Sağlık çalışanlarında AntiHBs pozitifliği ise \%65-81 arasında değişmekte iken bizim çalışmamızda \% 63

Tablo 3. Mesleklere göre aşıllanma oranları

\begin{tabular}{|c|c|c|c|c|c|c|}
\hline \multirow[b]{2}{*}{ Meslek } & \multicolumn{2}{|c|}{ Hepatit $B$ aşılanma durumu } & \multicolumn{4}{|c|}{ Tetanoz aşılanma durumu } \\
\hline & Yok n(\%) & $\operatorname{Var} n(\%)$ & Toplam n(\%) & Yok n(\%) & $\operatorname{Var} n(\%)$ & Toplam n(\%) \\
\hline Temizlik personeli (n:165) & $102(61,8)$ & $63(38,2)$ & $165(100)$ & $49(28,5)$ & $123(71,5)$ & $172(100)$ \\
\hline Hemşire (n:67) & $7(10,4)$ & $60(89,6)$ & $67(100)$ & $5(7,0)$ & $66(93,0)$ & $71(100)$ \\
\hline Sağllk teknisyeni (n:33) & $6(18,2)$ & $27(81,8)$ & $33(100)$ & $7(21,9)$ & $25(78,1)$ & $32(100)$ \\
\hline Sekreter (n:203) & $113(55,7)$ & $90(44,3)$ & $203(100)$ & $79(39,3)$ & $122(60,7)$ & $201(100)$ \\
\hline Toplam (n:468) & 22848,7 & $240(51,3)$ & $468(100)$ & $140(29,4)$ & $336(70,6)$ & $476(100)$ \\
\hline
\end{tabular}

* Aşılanma durumları anket sorularını yanıtlayanlar üzerinden değerlendirilmiştir. 
olarak saptandı (Aşkar, 2006; Demir ve ark., 2006; İnci ve ark., 2009; Öksüz ve ark., 2009; Yazıcı ve ark., 2010). Bağ1şıklık oranımız düşük olarak tespit edildi. Çalışmamızda populasyonun \%43'ünü oluşturan sekreter grubunda hasta vücut sıvılarıyla karşılaşma riskinin düşük olması nedeniyle bağışıklık oranları düşük olarak saptandı. Yapılan çalışmanın ardından sekreter grubunda da HBV enfeksiyonuna karşı aş1lama programı başlatıldı. Hemşire ve sağlık teknisyenlerinin \%90'dan fazlasının HBV enfeksiyonuna karşı bağışıklığı olduğu görüldü. Bu oranın daha önce yapılan birçok çalışmadan yüksek olduğu görüldü. Diyarbakır bölgesinde kronik hepatit B enfeksiyonunun endemik olması ve sağlık çalışanlarının bilgili ve duyarlı olmasının yüksek bağışıklık oranını saptamamıza neden olduğu düşünüldü. Ancak hasta ve vücut sıvıları ile sık karşılaşan temizlik personelinde bağışıklık oranı diğer riskli meslek gruplarına göre düşük $(\% 64,2)$ bulundu. Özellikle aşılı bağışık olma oranın \%26,6 ile oldukça düşük olması sebebiyle aşılama programına acilen başlanarak katılımın artırılması planlandı. Doğal bağışıklık oranı temizlik personelinde yüksek olarak tespit edildi $(\% 36,3)$. Bu durum riskli temasın fazla olmasına ve aşıya bağlı immünitenin düşük olmasına bağlandı. İnci ve ark.'nın yaptığı çalışmada ebe-hemşirelerin \%76,3'ünde, teknisyenlerin \%68,3'ünde, temizlik şirketi çalışanlarının \%43,9'unda ve diğer personelin \%37,5'inde anti-HBs seropozitif olarak bulundu. Aynı çalışmada aşılanma durumu sorgulandığında; ebe ve hemşirelerin $\% 54,2$ 'sinde aşıyla, \%22,0'ında doğal bağışıklık, teknisyenlerin \%51,2'inde aşıyla, \%17,1'sinde doğal bağışıllık, temizlik şirketi çalışanlarının \%29,8'inde aşıyla, \%14,0'ında doğal bağışıklık ve diğer personelin ise \%19,6'sında aşıyla \%17,9'unda doğal bağışıklık olduğu öğrenildi (İnci ve ark., 2009).

İnci ve ark.'nın yaptığı çalışma ile çalışmamız karşılaştırıldığında hemşire ve teknisyen grubunda aşıya bağlı bağıŞ1kl1k oranlarımız \%83,5, \%78,8 ile yüksek, temizlik personellerinde de doğal bağışıklığın \%36,3 ile fazla olduğu tespit edildi. Çalışmamızda serolojik belirteçlerden anti HBc total çalışılmadı. Doğal bağışıklığa, aşı olmayanlarda anti HBs seropozitifliğinin varlığı ile karar verildi. Ayrıca doğal bağış1k olup anti HBc total belirteci yapılmadığı için aşı yaptıran sağlık çalışanların olabileceği düşünülerek, gerçek doğal bağışıklık oranlarımızın daha yüksek olabileceği düşünülmektedir. CDC sağlık çalışanlarında aşı öncesinde rutin tetkik bakılmasını önermemekte (CDC, 2011), ancak ülkemizde; özellikle de çalışmamızın gerçekleştirildiği Diyarbakır endemik bölgesinde en azından HBsAg ve anti HBs bakılmasının gerektiği düşünülmektedir. Bu yaklaşımın belirtisiz seyreden kronik hepatit B enfeksiyonlu sağlık çalışanlarının tespiti için bir firsat olacağı ve uygunsuz olarak yapılan aşılamaları azaltacağ1 görüşündeyiz.

Tetanoz, sağlık çalışanlarında ve tüm erişkinlerde aşı ile korunulabilen birhastalıktır. 2000 yılında Ege Üniversitesi'nde yapılan bir çalışmada, sağlık çalışanlarının \%32,5'inin tetanoz aşısı yaptırdığ Bizim çalışmamızda tetanoz aşısı olma oranı \%70,6 idi. Bu oran özellikle hemşirelerde \%93'e yükselmekteydi. Cinsiyet karşılaştırması yapıldığında, kadınlarda fark istatistiksel olarak anlamlı olarak yüksekti. Hepatit aşılama oranlarında istatistiksel olarak anlamlı fark saptanmadı. Ülkemizde 15-49 yaş doğurganlık çağı kadınlarda Sağlık Bakanlığı Genişletilmiş Bağışıklama Programı ile Maternal ve Neonatal Tetanoz
Eliminasyon Programı kapsamında gebelikte en az 2 doz olacak şekilde toplam 5 doz tetanoz immünizasyonu önerilmekte olup çalışmamızda tespit edilen cinsiyetler arası istatistiksel olarak anlamlı farkın buna bağlı olabileceği düşünüldü (T.C. Sağlık Bakanlığı, 2006). DSÖ verilerine göre her yıl Avrupa'da 304 bin sağlık çalışanı HBV ile kontamine delici bir cisimle perkütan yaralanmaya maruz kalmaktadır (PrüssÜstün ve ark., 2003). Sağlık çalışanlarında görülen HCV enfeksiyonlarının \%39, HBV enfeksiyonlarının ise \%37'sinin, HIV enfeksiyonlarının ise \%4,4'ünün mesleki risklerle edinilmiş olduğu tahmin edilmektedir (Prüss-Üstün ve ark., 2003). Hepatit C prevalansı ve bulaşma yolları ülkeler ve bölgeler arasında değişkenlik göstermektedir. Ülkemiz dünya haritasında prevalansı \%1-1,9 arasında olan dilim içinde yer alır (Hou ve ark., 2005). Son yıllarda sağlık çalışanlarında antiHCV seroprevalansının araştırıldığı çalışmaların bir kısmında pozitiflik saptanmamış (Sarı ve ark., 2006; Güzelant ve ark., 2008), diğerlerinde de \%0,9'a kadar artan değerler bildirilmiştir (Aşkar, 2006; İnci ve ark., 2009; Öksüz ve ark., 2009; Yazıcı ve ark., 2010). Sağlık çalışanlarında, HCV enfeksiyonunun prevalans çalışmalarında diğer gruplarla karş1laştırıldığında minimal risk vardır. Aşkar ve ark yapmış olduğu çalışmada sağlık çalışanları ile kontrol grubunda antiHCV pozitifliği açısından bir fark tespit edilmemiştir (Aşkar, 2006). Hepatit C'li hasta kanı ile perkütan yaralanma sonrası antiHCV pozitifleşen 60 vaka ile gelişmeyen 204 kontrol sağlık çalışanında risk faktörlerinin araştırıldığ 10 yıllık dönemi kapsayan retrospektif çalışmada hastanın arter veya venine giren geniş delikli iğne ile ve ciddi yaralanmalarda bulaşma riskinin arttığı gösterildi. Aynı çalışmada erkek cinsiyet bir risk faktörü olarak bulundu (Yazdanpanah ve ark., 2005). Bizim çalışmamızda antiHCV seropozitifliği saptanmadı.

Perkütan temaslarda HIV enfeksiyonu bulaşma riski, HBV ve HCV enfeksiyonuna göre daha düşüktür. Enfekte hastanın kanıyla bir kez perkütan yoldan karşı karşıya kalış sonrası HBV, HCV ve HIV bulaşma riski sırasıyla \%6-30, $\% 3,5-10$ ve \%0,18-0,46 arasında değişmektedir (Yazıcı ve ark., 2010). Sağlık çalışanlarımızda antiHIV seropozitifliği saptanmadı. Toplumda düşük oranda görülmesine ve bulaşma riskinin düşük olması nedeniyle seropozitifliğin saptanmadığı düşünüldü. Van'da kan donörlerinde 9 yılı kapsayan tarama testlerinde $\mathrm{HBsAg}$, tüm donörlerin \%2,55'inde pozitif olarak bulunurken, anti-HCV, anti-HIV ve VDRL pozitifliği sira ile tüm donörlerin $\% 0,17, \% 0,036, \% 0,057$ 'sinde pozitif saptanmıştır (Dilek ve ark., 2007). Sağlık çalışanlarımızda kanla bulaşabilen hastalıklar içinde sifilizin de olması nedeniyle VDRL taraması yapıldı. Seropozitiflik saptanmadı.

Sonuç olarak çalışmamızda tespit edilen HBV enfeksiyonu prevalansı ülkemiz verileri ile uyumlu bulundu, diğer kanla bulaşabilen hastalıklardan HCV, HIV, sifiliz taramasında seropozitiflik saptanmadı. Hemşire ve sağlık teknisyenlerinde HBV aşılama oranları yüksek olmakla birlikte hizmet satın alma yoluyla çalışan temizlik personelinde aşılanma oranlarının düşük olması nedeniyle iyileştirilmesi ve bulaşıc1 hastalıklar ile ilgili öncelikle eğitim yoluyla bilinçlendirilmesi gerekmektedir. Tetanoz aşılanma oranı kadın sağlık çalışanlarında daha yüksek olmakla beraber tüm personelin tetanoza karşı aşılanmasının sağlanması gerekmektedir. İmmünizasyon çalışmalarının yanı sıra perkütan yaralanmaların ve mukozal temasların minimum düzeye indirilmesi için standart enfeksiyon kontrol önlemlerinin alınması amacıy- 
la sürekli hizmet içi eğitim verilmesi ve sağlık çalışanlarına yerinde uygulamalı olarak pratiğin yapılması gereklidir. Kesici-delici alet yaralanmaları ve riskli mukozal temaslar takip edilmelidir. Bu konuda bilinçlendirilmenin arttırılarak, gerekli düzeltici ve önleyici tedbirlerin alınması sağlanmalıdir.

\section{KAYNAKLAR}

Aşkar, E., 2006. Sağlık çalışanlarında hepatit B ve hepatit C seroprevalansı. Şişli Etfal Eğitim ve Araştırma Hastanesi Enfeksiyon Hastalıkları ve Klinik Mikrobiyoloji Kliniği, Uzmanlık tezi, İstanbul.

Barut, H.Ş., Günal, Ö., 2009. Dünyada ve ülkemizde hepatit C epidemiyolojisi. Klimik Dergisi. 22, 38-43.

CDC, 2011. Immunization of Health-Care Personnel. Recommendations of the Advisory Committee on Immunization Practices (ACIP). MMWR. 60 (No.RR07), 1-45.

Demir, İ., Kaya, S., Demirci, M., Arıdoğan, B.C., 2006. Isparta ili sağlık personelinde hepatit B virus seropozitifliğinin araştırılması. İnfeksiyon Derg. 20, 183-187.

Dilek, İ., Demir, C., Bay, A., Akdeniz, H., Öner, A.F., 2007. Türkiye'nin doğu bölgesindeki kan donörlerinde HBsAg, anti-HCV, anti-HIV ve VDRL seropozitivite oranlar1. Turk. J. Hematol. 24, 4-7.

Güzelant, A., Kurtoğlu, M.G., Kaya, M., Keşli, R., Baysal, B., 2008. Kan vericilerinde ve bir ağız-diş sağlığı merkezi çalışanlarında Hepatit B, Hepatit C ve HIV seroprevalansı ile vericilerde risk faktörlerinin araştırılması. İnfeksiyon Derg. 22, 189-195.

Hepatit B Güncelleme: Hepatit B güncelleme toplantıs1, 12-13 Ocak 2007, Hilton -İstanbul, Toplantı Kitapçı̆̆1, pp:28

Hou, J., Liu, Z., Gu, F., 2005. Epidemiology and Prevention of Hepatitis B Virus Infection Int. J. Med. Sci. 2, 50-57.

İnci, M., Aksebzeci, A.T., Yağmur, G., Kartal, B., Emiroğlu, M., Erdem, Y., 2009. Hastane çalışanlarında HBV, HCV ve HIV seropozitifliğinin araştırılması. Türk Hij. Den. Biyol. Derg. 66, 59-66.

Mast, E.E., Alter, M.J., 1993. Prevention of hepatitis B virus infection among health-care workers. In: Ellis RE, editor. Hepatitis B Vaccines in Clinical Practice. New York: Marcel Dekker, 295-307.

Mıstık, R.,2007. Ülkemizde Kronik Viral Hepatitlerin Epidemiyolojisi. XIII. Türk Klinik Mikrobiyoloji ve Enfeksiyon Hastalıkları Kongresi. Klimik Dergisi. 20 (özel sayı 1): 61-63.

Öksüz, Ş., Yıldırım, M., Özaydın, Ç., Şahin, İ., Arabacı, H., Gemici, G., 2009. Bir devlet hastanesi çalışanlarında HBV ve HCV seroprevalansının araştırılmas1. ANKEM Derg. 23,30-33.

Prüss-Üsstün A, Rapiti E, Hutin Y. 2003. Sharps injuries: global burden of disease from sharps injuries to health-care workers. Geneva, World Health Organization (WHO Environmental Burden of Disease Series, No. 3).

Sarı, N., Günal, Ö., Dizbay, M., Hızel, K., Aktaş, F., 2006. Bir üniversite hastanesinde temizlikten sorumlu şirket elemanlarında ve sözleşmeli hemşirelerde HBsAg ve Anti-HCV sıklı̆̆ının araştırılması. Viral Hepatit Dergisi. 11, 126-131.

Taşyaran, M.A., 1998. Epidemiyoloji. Kılıçturgay K ed. Viral Hepatit 98. 1. bask1. Viral Hepatit Savaşım Derneği Yayını. Ankara: Deniz Ofset, 94-100.

T.C. Sağlık Bakanlığı -2006. Maternal ve Neonatal Tetanoz Eliminasyon Programı Saha Rehberi. pp:23

Türkistanlı, E., Şenuzun, F.E., Karaca, B.S., San, A.T., Aydemir, G., 2000. Ege Üniversitesi Tıp Fakültesi Araştırma ve Uygulama Hastanesinde sağlık çalışanlarının bağışıklama durumu. Ege Tıp Dergisi. 39, 29-32.

UNAIDS, (2010). HIV/AIDS Epidemiyolojik verileri: Türkiye.

WHO, 2008. Hepatitis B. World Health Organisation, Department of Communicable Diseases Surveillance and Responce. www.who.int/csr/ disease/hepatitis/whocdscsrlyo20022/en/. pp:6

Yazdanpanah, Y., De Carli, G., Migueres, B., 2005. Risk factors for hepatitis C virus transmission to health care workers after occupational exposure: a European case-control study. Clin. Infect. Dis. 41, 1423-1430.

Yazıcı, Y., Demir, N., Çınarka, H., Yılmaz, H., Altıntaş, N., 2010. Trabzon gögüs hastalıkları hastanesi çalışanlarında HBV, HCV ve HIV seroprevalansı. Türk Hij. Den. Biyol. Derg. 67, 27-32. 